\title{
CHARAKTERYSTYKA QUASI-SĄDOWYCH FUNKCJI EUROPEJSKIEGO KOMITETU PRAW SPOLECZNYCH W PROCESIE ROZPATRYWANIA SKARG ZBIOROWYCH*
}

\section{EUROPEJSKI KOMITET PRAW SPOŁECZNYCH JAKO ORGAN TRAKTATOWY W DZIEDZINIE MIĘDZYNARODWEJ OCHRONY PRAW CZLOWIEKA}

\section{Uwagi wprowadzające}

Dynamiczny rozwój międzynarodowego prawa praw człowieka w ciagu ostatnich kilkudziesięciu lat przebiegał i przebiega na wielu płaszczyznach. Rozwój ten oznacza nie tylko stanowienie nowych regulacji normatywnych, wzbogacających obszerny katalog praw człowieka i podstawowych wolności, lecz także stanowienie nowych, zinstytucjonalizowanych i coraz bardziej efektywnych mechanizmów ich międzynarodowej kontroli. Rozwój ten powoduje nadto, że klasyczny, uniwersalny system międzynarodowej ochrony praw człowieka w ramach Organizacji Narodów Zjednoczonych został w istotny sposób rozbudowany i wzbogacony o systemy regionalne z własnymi, szeroko rozbudowanymi i efektywnymi systemami kontrolnymi. Mimo że koncepcja regionalizmu w międzynarodowej ochronie praw człowieka była poddawana krytyce, jako pociagająca za sobą ryzyko osłabienia systemu ochrony uniwersalnej, jak również ryzyko potencjalnej kolizji norm uniwersalnych z normami regionalnymi, to można sformułować tezę, że w praktyce implementacji międzynarodowego prawa praw człowieka ochrona podstawowych praw i wolności jest silniejsza i bardziej rozbudowana w systemach regionalnych. Oceniając te relacje, niektórzy autorzy wyraźnie stwierdzaja, że dopóki uniwersalny system ochrony praw człowieka nie doczeka się głębokiej reformy, zwłaszcza w zakresie instrumentów kontrolnych, ciężar urzeczywistniania idei skutecznej ochrony i skutecznej kontroli będzie spoczywał na systemach regionalnych ${ }^{1}$.

Najlepszym przykładem ewolucji dynamicznego i efektywnego regionalnego systemu międzynarodowej ochrony praw człowieka jest bez wątpienia system Rady Europy, w którym znajdujemy wzorcowe rozwiąania prawne i instytucjo-

\footnotetext{
* Artykuł został przygotowany w ramach projektu naukowego finansowanego przez Narodowe Centrum Nauki (NCN Preludium 8 nr 2014/15/N/HS5/00662).

1 Zob. np. M. Lubiszewski, Kodyfikacja ochrony praw człowieka w systemach regionalnych, w: B. Gronowska et al., Prawa człowieka i ich ochrona, Toruń 2010, s. 79.
} 
nalne oraz najbardziej efektywne mechanizmy kontrolne. Analiza postanowień Statutu Rady Europy oraz jej dorobku normatywnego upoważnia do wyrażenia stanowiska, że żadna inna znacząca organizacja międzynarodowa nie została oparta na fundamentach tak mocno i jednoznacznie związanych z przestrzeganiem praw człowieka ${ }^{2}$. Na gruncie praktyki natomiast należy podkreślić imponujący dorobek traktatowy Rady Europy w tej dziedzinie. Pośród ponad 200 konwencji i protokołów, jakie znajdujemy w ogólnym dorobku traktatowym Rady Europy, pierwszoplanowe miejsce zajmuja regulacje normatywne w dziedzinie ochrony praw człowieka ${ }^{3}$. Charakterystyczne jest to, że w działalności normatywnej Rady w tej materii w pierwszych latach jej funkcjonowania wyraźna była tendencja do koncentrowanie się na kodyfikacji praw obywatelskich i politycznych, które w według klasycznej koncepcji trzech generacji praw człowieka zaliczone zostały do praw pierwszej generacji ${ }^{4}$. Najbardziej znaczącym osiagnięciem Rady Europy w tej dziedzinie było niewątpliwie podpisanie w Rzymie 4 listopada 1950 r. Konwencji o Ochronie Praw Człowieka i Podstawowych Wolności (EKPC, Konwencja) ${ }^{5}$. Nie oznacza to oczywiście, że Rada nie doceniała wagi i znaczenia praw człowieka zaliczanych do praw drugiej generacji, a zwłaszcza praw socjalnych. Nie ulega jednak wątpliwości, że proces kodyfikacji praw człowieka w ramach Rady Europy przebiegał w sposób zróżnicowany czasowo, co oznaczało, że najpierw i szybciej kodyfikowane były prawa obywatelskie i polityczne, a następnie prawa gospodarcze i socjalne ${ }^{6}$. Przyczyny takiego stanu rzeczy były zróżnicowane, ale zasadniczo wynikały one ze sposobu postrzegania poszczególnych kategorii praw człowieka w ustawodawstwie wewnętrznym poszczególnych państw, co bez wątpienia rzutowało na przebieg procesu ich internacjonalizacji i w konsekwencji także kodyfikacji ${ }^{7}$.

\section{System Europejskiej Karty Społecznej}

Współczesny dorobek traktatowy Rady Europy w zakresie kodyfikacji praw człowieka drugiej generacji obejmuje regulacje normatywne określane zwykle jako system Europejskiej Karty Społecznej (EKS, Karta). System ten można

${ }^{2}$ P. Świtalski, Miejsce Rady Europy w europejskiej architekturze instytucjonalnej, w: H. Machińska (red.), 60 lat Rady Europy. Tworzenie $i$ stosowanie standardów prawnych, Warszawa 2009, s. 15; A. Gadkowski, Europejski Komitet Praw Społecznych w systemie organów traktatowych międzynarodowej ochrony praw człowieka, „Adam Mickiewicz University Law Review” 3, 2014, s. 71 i n.

${ }^{3}$ Treaty Office of the Council of Europe, http://www.coe.int/en/web/conventions/ [dostęp: 19.08.2016].

${ }^{4} \mathrm{~K}$. Vasak, Le droit international des droits de l'homme, „Revue des Droits de l'Homme” 1 , 1972, s. 43 i n.; zob. też K. Drzewicki, Trzecia generacja praw cztowieka, „Sprawy Międzynarodowe” 1983, nr 10, s. 83 i n.

${ }^{5}$ ETS No. 005 (tekst polski: Dz. U. 1993, Nr 61, poz. 284 ze zm.).

${ }^{6}$ Dla oznaczenia tych procesów przyjmuje się zwykle określenia: double-track i double-speed; zob. np. A. Gadkowski, Prawa socjalne w systemie Europejskiej Karty Spotecznej, w: Z. Dziemianko, W. Stach, Bezpieczeństwo i prawa człowieka w badaniach młodych naukowców, Poznań 2014, s. 73 .

${ }^{7}$ K. Drzewicki, Prawa socjalne w Radzie Europy, w: H. Machińska (red.), Polska i Rada Europy 1999-2002, Warszawa 2005, s. 138; K. Łasak, Prawa społeczne w orzecznictwie Europejskiego Trybunału Praw Człowieka, Warszawa 2013, s. 15-16. 
postrzegać jako uzupełnienie znacznie bardziej znanego w strukturze Rady Europy i znacznie częściej dyskutowanego systemu EKPC ${ }^{8}$. Nie można jednak nie zauważyć, że ta właśnie Konwencja, inspirowana bez wątpienia treścia Powszechnej Deklaracji Praw Człowieka z 1948 r., stanowi, wraz z protokołami dodatkowymi, najbardziej zaawansowany i efektywny system regionalnej ochrony praw człowieka, dysponujący środkami efektywnej kontroli międzynarodowej, włącznie z procedurami sądowymi w ramach Europejskiego Trybunału Praw Człowieka (ETPC) ${ }^{9}$.

System EKS jest dosyć obszerny i zróżnicowany. Jego podstawę stanowia dwie konwencje Rady Europy: Europejska Karta Społeczna i Zrewidowana Europejska Karta Społeczna (ZEKS). Ta pierwsza została podpisana w Turynie 18 października 1961 r. i weszła w życie 26 lutego 1965 r. ${ }^{10}$ Jej stronami jest aktualnie 27 państw członkowskich Rady Europy ${ }^{11}$. Polska ratyfikowała Kartę 25 czerwca 1997 r., a weszła ona w życie w stosunku do Polski 25 lipca 1997 r. ${ }^{12}$ Natomiast ZEKS podpisana została w Strasburgu 3 maja 1996 r. i weszła w życie 1 lipca 1999 r. ${ }^{13}$ Jej stronami są aktualnie 34 państwa członkowskie Rady Europy ${ }^{14}$. Polska dotychczas jej nie ratyfikowała. Istotna częścią systemu Karty pozostają dwa protokoły dodatkowe i jeden protokół zmieniający. Są to: Protokół dodatkowy z 5 maja 1988 r., który wszedł w życie 4 września 1992 r. ${ }^{15}$ i który został przyjęty w następstwie wcześniejszego uchwalenia przez Radę Europy Deklaracji o Prawach Człowieka z 27 kwietnia 1978 r. ${ }^{16}$, Protokół dodatkowy z 9 listopada 1995 r., który wszedł w życie 1 lipca 1998 r. ${ }^{17}$ oraz Protokół zmieniajacy z 21 października 1991 r., podpisany w 30 rocznice podpisania samej Karty ${ }^{18}$.

Nie ulega wątpliwości, że efektywność regulacji prawnych międzynarodowego prawa praw człowieka zależy przede wszystkim od jakości i skuteczności określonych w nich instytucji i mechanizmów kontrolnych. Taki mechanizm kontrolny funkcjonuje również w systemie EKS. Karta stworzyła własny

${ }^{8}$ R. Brillat, La Charte sociale européenne du Conseil de l'Europe: Développements récents, „Droit en Quart Monde” 1996, nr 12, s. 37.

${ }^{9}$ M. A. Nowicki, Wokół Konwencji Europejskiej, Warszawa 2009.

10 ETS No. 035.

11 Treaty Office of the Council of Europe, http://www.coe.int/en/web/conventions/ [dostęp: 19.08.2016].

${ }^{12}$ Dz. U. 1999, Nr 8, poz. 67 ze zm. Analiza postanowień Karty zob. np. A. Świątkowski, Prawo socjalne Rady Europy, Kraków 2006, s. 12 i n.

${ }^{13}$ ETS No. 163.

${ }^{14}$ Treaty Office of the Council of Europe, http://www.coe.int/en/web/conventions/ [dostęp: 19.08.2016].

${ }_{15}$ ETS No. 128.

16 A. Świątkowski, Karty Społeczne Rady Europy, „Państwo i Prawo” 2003, z. 8, s. 38. Stronami tego Protokołu jest aktualnie 13 państw członkowskich Rady Europy. Polska dotychczas nie ratyfikowała Protokołu.

17 Tekst Protokołu: ETS No. 158. Jego stronami jest aktualnie 15 państw. Polska dotychczas nie ratyfikowała Protokołu.

18 ETS No. 142. Protokół ten nie wszedł jeszcze w życie, a jego stronami są 23 państwa strony Europejskiej Karty Społecznej. Polska ratyfikowała Protokół 25 czerwca 1997 r. (tekst polski: Dz. U. 1999, Nr 8, poz. 67 ze zm.). 
system kontrolny, który przeszedł wyraźną ewolucję. Pierwotny system kontrolny określają postanowienia części IV Karty z 1961 r. (art. 21-29). Przepisy te tworzą mechanizm nadzoru nad przestrzeganiem jej postanowień. Przewidują one sprawozdania państw oraz określają status organu kontrolnego, jakim był Komitet Ekspertów. Mechanizm ten zmodyfikował Protokół zmieniający z 1991 r., który zmienił nazwę organu traktatowego Karty na Komitet Niezależnych Ekspertów, zwiększając liczbę jego członków i przyznając mu wyłączne prawo interpretowania i stosowania przepisów Karty ${ }^{19}$. Od 1998 r. organ ten nosi nazwę: Europejski Komitet Praw Społecznych (EKPS, Komitet).

Najbardziej istotna modyfikację systemu kontrolnego EKS wprowadził Protokół dodatkowy z 1995 r. Pierwszorzędną i najbardziej rozpoznawalna jego cechą jest to, że wprowadził do systemu kontrolnego Karty instytucję skarg zbiorowych ${ }^{20}$. Wprowadzając ten instrument kontrolny, Protokół przyznał międzynarodowym i krajowym organizacjom pracodawców i pracowników oraz określonym organizacjom pozarządowym prawo wnoszenia skarg na państwa członkowskie Rady Europy - strony Karty i Protokołu - w sytuacjach niezgodnego z przyjętymi standardami wykonywania przez nie przyjętych zobowiązań. Niektórzy autorzy podkreślają w związku z tym, że wyposażając EKPS w kompetencje do rozpatrywania skarg zbiorowych i przewidując $\mathrm{w}$ tej mierze określona procedurę, Protokół upodobnił Komitet do organu traktatowego o charakterze quasi-sadowym ${ }^{21}$.

Charakteryzując bardzo ogólnie EKPS jako organ traktatowy międzynarodowego prawa praw człowieka, można sformułować tezę, że w pewnym sensie jest on odpowiednikiem Komitetu Praw Gospodarczych, Społecznych i Kulturalnych w systemie Międzynarodowego Paktu Praw Gospodarczych, Społecznych i Kulturalnych. Dalej można powiedzieć, że z uwagi na swoje quasi-sądowe funkcje jest on odpowiednikiem ETPC w systemie EKPC.

\section{KOMPETENCJE EUROPEJSKIEGO KOMITETU PRAW SPOŁECZNYCH}

Gdyby chcieć w sposób najbardziej ogólny, a zarazem trafny określić kompetencje EKPS jako organu traktatowego Rady Europy w dziedzinie ochrony praw człowieka, to należałoby powiedzieć, że Komitet nadzoruje przestrzeganie przez państwa członkowskie tej organizacji postanowień traktatowych, składających się na system Europejskiej karty społecznej. W ramach tak ogólnie określonych kompetencji EKPS:

19 A. Świątkowski, Karty Społeczne..., s. 39-40.

${ }^{20}$ Komentarz zob. np. R. R. Churchill, U. Khaliq, The collective complaints system of the European Social Charter: an effective mechanism for ensuring compliance with economic and social rights?, „European Journal of International Law” 15(3), 2004, s. 417 i n.

${ }_{21}$ A. Brillat, op. cit., s. 52 i n.; M. Jager, The Additional Protocol to the European Social Charter providing for a system of collective complaints, „Leiden Journal of International Law” 10(1), 1997, s. 69 i n.; A. Świątkowski, Quasi-jurysdykcyjna funkcja Komitetu Praw Społecznych Rady Europy, „Państwo i Prawo” 2004, z. 9, s. 46 i n. 
1) ustanawia europejskie standardy w zakresie prawa pracy, zabezpieczenia społecznego i polityki społecznej;

2) analizuje sprawozdania przygotowane i przekazane przez państwa i orzeka o zgodności lub niezgodności przepisów krajowych ze standardami ustanawianymi na podstawie traktatów składających się na system EKS, a następnie formułuje pozbawione mocy prawnie wiążącej konkluzje, które sa przekazywane do Komitetu Rządowego, a stąd do Komitetu Ministrów Rady Europy;

3) rozpoznaje skargi zbiorowe wnoszone przez uprawnione podmioty przeciwko państwom naruszającym zobowiązania przyjęte w systemie Karty, przygotowując końcowy raport w sprawie konkretnej skargi, na podstawie którego Komitet Ministrów Rady Europy uchwala odpowiednią rezolucję lub rekomendację.

Analizowanie sprawozdań państw oraz rozpatrywanie skarg to procedury, które upodabniają EKPS do innych organów traktatowych w procesie implementacji norm międzynarodowego prawa praw człowieka. Z drugiej jednak strony status Komitetu na tle innych organów traktatowych jest szczególny, jako że w ramach procedury rozpatrywania skarg zbiorowych upodabnia się on do organu sądowego, choć takim w istocie rzeczy nie jest.

Z uwagi na zasygnalizowaną wyżej dwutorowość kodyfikacji międzynarodowego prawa praw człowieka w ramach Rady Europy, instrumenty kontrolne przewidziane pierwotnie w systemie EKS były wyraźnie słabsze od tych, jakie zostały przewidziane w systemie EKPC. W procesie implementacji postanowień tej Konwencji przewidziano bowiem bardzo dobrze rozbudowany i skuteczny system skargowy z ETPC jako organem o charakterze sądowym. Natomiast w procesie implementacji postanowień EKS przewidziano pierwotnie tylko klasyczny system sprawozdań, co rodziło oczywiste dysproporcje pomiędzy możliwością korygowania naruszeń przez państwa postanowień obu tych traktatów: z jednej strony za pomoca metod skargowych przed organem sądowym, a z drugiej - metod sprawozdawczych przed klasycznym organem traktatowym. Stąd też, aby w odpowiednim stopniu wyrównać poziom ochrony praw politycznych oraz praw gospodarczych i socjalnych w systemie Rady Europy, wprowadzono do tego systemu instytucje i procedurę skargi zbiorowej. Stało się to za sprawą podpisanego w 1995 r. Protokołu dodatkowego. Protokół ten przyznał międzynarodowym i krajowym organizacjom pracodawców i pracowników oraz określonym organizacjom pozarządowym prawo wnoszenia skarg na państwa członkowskie Rady Europy - strony Karty i Protokołu, w sytuacjach niezgodnego z przyjętymi standardami wykonywania przez nie przyjętych zobowiązań. Na tej właśnie podstawie niektórzy autorzy uważaja, iż Protokół, wyposażając EKPS $\mathrm{w}$ kompetencje do rozpatrywania skarg zbiorowych i przewidujac w tej mierze specjalną procedurę, upodobnił ten organ traktatowy do organu o charakterze quasi-sądowym ${ }^{22}$.

\footnotetext{
${ }^{22}$ Zob. np. D. Harris, J. Darcy, The European Social Charter, Ardsley 2001, s. 366.
} 


\section{QUASI-SĄDOWY CHARAKTER DZIAŁALNOŚCI KOMITETU W PROCESIE ROZPATRYWANIA SKARG ZBIOROWYCH}

\section{Istota i klasyfikacja skarg w systemie międzynarodowej ochrony praw człowieka}

W systemach kontrolnych międzynarodowego prawa praw człowieka szczególnie ważną rolę odgrywaja skargi, które są bardzo ważnym instrumentem jego implementacji. Cechą charakterystyczną skargi jest jej legitymacja bierna. Skargę wnosi się bowiem przeciwko państwu. Skargi występuja zarówno w procedurze sądowej, jak i w procedurze kontrolnej przed organami traktatowymi, które nie są sądami. Różne są przesłanki wnoszenia skarg, ale nie jest to kryterium istotne z punktu widzenia ich klasyfikacji. Wydaje się, że najważniejsza jest strona podmiotowa, a więc podmiot lub podmioty wnoszące skargę, w związku z czym zasadniczym kryterium klasyfikacji skarg jest ich legitymacja czynna. Istota tego instrumentu kontrolnego polega bowiem na zawiadomieniu kompetentnych organów międzynarodowych o naruszeniu praw człowieka przez państwo lub jego organy ${ }^{23}$. Podmiotem, który skargę kieruje, mogą więc być: ofiara takiego naruszenia, która działa w imieniu własnym i we własnym interesie; podmiot uprawniony, który działa w imieniu lub w interesie takiej ofiary, jak również podmiot uprawniony, który działa we własnym imieniu, ale w interesie ogólnym. Katarzyna Łasak pisze w związku z tym, że właściwa nazwa skargi jest kwalifikowana przez przydawkę wskazująca na uprawnionego do zawiadomienia organu kontrolnego o nieprzestrzeganiu zobowiązań traktatowych. $\mathrm{Z}$ tego punktu widzenia przyjmuje się zwykle następującą klasyfikację skarg:

1) skargi indywidualne, a więc skargi wnoszone przez jednostki lub grupy jednostek. Moga one być wnoszone zarówno przez osoby fizyczne, jak i przez osoby prawne. Sa one kierowane zarówno do organów traktatowych o charakterze sądowym, jak i pozasądowym. Z uwagi na indywidualny interes prawny podmiotu wnoszacego taką skargę nie przybieraja one kształtu actio popularis;

2) skargi międzypaństwowe, a więc skargi wnoszone przez państwa. Ich istota sprowadza się do umożliwienia państwom stronom traktatu zaskarżenia innego państwa strony do traktatowego organu kontrolnego o charakterze sądowym lub pozasądowym w sytuacji, w której państwo skarżące podnosi, że zaskarżane państwo nie wypełnia swoich traktatowych zobowiązań. Z uwagi na to, że zobowiazania w zakresie przestrzegania praw człowieka maja charakter zobowiąań erga omnes, państwo skarżące nie musi wykazywać faktu naruszenia własnego interesu, przez co taka skarga państwowa przybiera kształt actio popularis;

3) skargi wnoszone przez uprawnione podmioty, np. przez pozarządowe organizacje międzynarodowe, które możemy kwalifikować bądź to jako skargi indywidualne, bądź to jako skargi zbiorowe ${ }^{24}$.

${ }^{23}$ Szerzej zob. A. Gadkowski, Les réclamations collectives dans le système de la Charte sociale européenne, „Cahiers Genevois et Romands de Sécurité Sociale” 2011, nr 46, s. 39.

${ }^{24}$ Szerzej zob. K. Łasak, Warunki dopuszczalności skargi zbiorowej w systemie Europejskiej Karty Spotecznej, w: H. Machińska (red.), Polska i Rada Europy..., s. 237 i n. 
W kontekście takiej klasyfikacji skarg funkcjonujących w systemach kontrolnych międzynarodowego prawa praw człowieka należy zaprezentować problematykę skarg zbiorowych kierowanych do EKPS i rozpatrywanych przez ten traktatowy organ kontrolny.

\section{Skargi zbiorowe w systemie Europejskiej Karty Społecznej}

Instytucja skarg zbiorowych kierowanych do EKPS znacząco odbiega od standardowych rozwiązań dotyczących instytucji skarg jako środka kontrolnego wykorzystywanego w działalności innych organów traktatowych. Protokół dodatkowy z 1995 r. jest wzorowany na procedurze kontrolnej Komitetu Wolności Związkowej Międzynarodowej Organizacji Pracy, który został ustanowiony przez Radę Administracyjną Międzynarodowego Biura Pracy w $1951 \mathrm{r}^{25}$ Protokół ten przyznał międzynarodowym i krajowym organizacjom pracodawców i pracowników oraz określonym organizacjom pozarządowym prawo wnoszenia skarg na państwa członkowskie Rady Europy - strony Karty i Protokołu w sytuacjach niezgodnego z przyjętymi standardami wykonywania przez nie zobowiąań traktatowych w zakresie realizacji szeroko pojętych praw socjalnych. To ostatnie zdanie bardzo dobrze oddaje istotę skargi zbiorowej na tle klasycznej kwalifikacji skarg na indywidualne i międzypaństwowe. Określa bowiem locus standi podmiotów uprawnionych do składania skargi w sposób odbiegający od standardów skargi indywidualnej i międzypaństwowej. Powoduje to, że skarga taka, chociaż nie jest składana przez państwo lub państwa, zbliża się swoim charakterem do actio popularis, co jest cechą skargi międzypaństwowej, a nie indywidualnejej.

Skargi zbiorowe mogą być składane w interesie wszystkich osób, a nie tylko pracowników lub ubezpieczonych pozostających pod władzą państwa strony systemu Karty, jeżeli państwo to, regulując w swoim porządku prawnym sytuacje wszystkich lub wybranych kategorii społecznych, nie stosuje się do postanowień Karty i standardów ochrony określonych na podstawie tych postanowień. Andrzej Świątkowski podkreśla w związku z tym, że skarga zbiorowa może być wniesiona $\mathrm{w}$ razie potrzeby ochrony interesów i praw określonej zbiorowości, a nie jednostki. Autor podkreśla przy tym, że uznaniu skargi za zbiorową nie sprzeciwia się możliwość identyfikowania osób, na rzecz których skarga została złożona ${ }^{27}$. Regulacje proceduralne określające sposób rozpatrywania takiej skargi przez EKPS, który z istoty swej nie jest organem sądowym, powoduja, że realizuje on kompetencje organu o charakterze quasi-sądowym.

${ }^{25}$ H. Wierzbicka, Międzynarodowa Organizacja Pracy $i$ Rada Europy w aspekcie polskiego prawa pracy. Studia z zakresu prawa pracy i polityki społecznej, Kraków 1965, s. 171 i n.; $\mathrm{N}$. Valticos, Les normes de l'OIT en matière de protection des droits de l'homme, „Revue des Droits de l'Homme" 4, 1971, s. 691; Un système de contrôle international: la mise en œeuvre des conventions internationales du travail, „Recueil des Cours de l'Académie de Droit International de La Haye" 123, 1968, s. 377.

${ }^{26}$ J. M. Belorgey, La Charte sociale en pratique: la jurisprudence du Comité européen des droits sociaux, „Revista Europea de Derechos Fundamentales” 13(1), 2009, s. 245 i n.

${ }^{27}$ A. Świątkowski, Prawo socjalne..., s. 255-256. 
Interesujące są również inne cechy skargi zbiorowej w systemie EKS. Nie stanowi bowiem formalnej przeszkody do jej rozpoznania ani zarzut sprawy zawisłej przed innym organem, ani nawet zarzut sprawy osądzonej (res iudicata). W postępowaniu wszczętym skargą zbiorową nie ma zastosowania zakaz powtórnego wyrokowania w jednej sprawie (ne bis in idem). Dla przykładu, sprawy o naruszenie wolności związkowej są rozpatrywane przez Komitet Wolności Związkowych Międzynarodowej Organizacji Pracy, a także przez EKPS. W związku z tym wniesienie skargi do jednego z tych organów kontrolnych nie pozbawia podmiotu skarżącego uprawnienia do domagania się interpretacji i oceny prawnej norm zbiorowego prawa pracy w danym państwie pod kątem ich zgodności czy to z Konwencją nr 87 MOP z 17 czerwca 1948 r. w sprawie wolności związkowych i ochrony praw związkowych, czy to z EKS i jej systemem ${ }^{28}$. Podobnie rozpatrywanie sprawy przez EKPS w ramach procedury sprawozdań nie jest przeszkodą do wniesienia w tej sprawie skargi przez uprawnione podmioty do Komitetu Wolności Związkoweje ${ }^{29}$. Ponadto bez znaczenia jest upływ czasu, niepowodujacy w tym przypadku utraty prawa do wniesienia skargi. Szczególnie interesująca cechą skargi zbiorowej jest brak konieczności wyczerpania drogi postępowania krajowego dla skutecznego wniesienia skargi, co odbiega od tradycyjnej zasady rządzącej systemem ochrony praw człowieka, a więc zasady subsydiarności ${ }^{30}$.

\section{Locus standi podmiotów uprawnionych do składania skarg zbiorowych}

O zbiorowym charakterze skarg wnoszonych do EKPS świadczy sposób określenia locus standi podmiotów uprawnionych do ich składania. Na mocy postanowień art. 1 Protokołu dodatkowego z 1995 r. skargi zbiorowe moga składać podmioty uprawnione w sytuacjach niezadowalajacego stosowania EKS przez państwa strony. Krag tych podmiotów, które mają czynną legitymację do wniesienia skargi, jest następujący:

1) międzynarodowe organizacje pracodawców i pracowników, o których mowa w ustępie 2 art. 27 Karty. Są to aktualnie: jedna międzynarodowa centrala związków zawodowych - Europejska Konfederacja Związków Zawodowych i dwie międzynarodowe organizacje pracodawców - Business Europe i Międzynarodowa Organizacja Pracodawców;

2) inne międzynarodowe organizacje pozarządowe, mające status doradczy przy Radzie Europy, a więc takie, którym Rada Europy przyznała prawo wyrażania stanowiska i które zostały umieszczone na liście sporządzonej w tym celu przez Komitet Rządowy. Obecnie na liście tej znajdują się 72 organizacje, takie jak np. Amnesty International i International Association of Lawyers ${ }^{31}$;

28 Dz. U. 1958, Nr 29, poz. 125.

29 A. Światkowski, Prawo socjalne..., s. 256 i n.

${ }^{30}$ Stanowisko Komitetu zob.: Réclamation No. 26/2004, la Syndicat des Agrégés de l'Enseignement supérieur c. France.

31 Zob. http://www.coe.int/en/web/turin-european-social-charter/non-governmental-organisations-entitled-to-lodge-collective-complaints/ [dostęp: 19.08.2016]. 
3) reprezentatywne krajowe organizacje pracodawców i pracowników, mające prawo do prowadzenia działalności w granicach podlegajacych jurysdykcji państwa członkowskiego Rady Europy, przeciwko któremu będą miały prawo wniesienia skargi zbiorowej ${ }^{32}$.

4) podmioty uprawnione na mocy postanowień art. 1 pkt 2 Protokołu. Przepis ten przewiduje możliwość poszerzenia tak zakreślonego kręgu podmiotów uprawnionych do składania skarg zbiorowych. Wynika z niego, że każde państwo strona może w momencie wyrażania zgody na związanie się Protokołem, w zgodzie z postanowieniami art. 13 lub w okresie późniejszym oświadczyć, że uznaje prawo wniesienia przeciwko niemu skargi przez inne reprezentatywne krajowe organizacje pozarządowe podlegające jego jurysdykcji, które są właściwe w sprawach uregulowanych w Karcie ${ }^{33}$.

W związku z problematyką podmiotów uprawnionych należy pamiętać o tym, że w praktyce funkcjonowania systemu skarg zbiorowych Komitet bada legitymację konkretnej organizacji do wnoszenia skargi ${ }^{34}$. Decyduje więc o dopuszczalności skargi lub jej braku. Można więc powiedzieć, że już na tym etapie Komitet wypełnia funkcje quasi-sądowe.

\section{Dopuszczalność skargi - warunki ratione materiae}

Skarga zbiorowa może być skierowana tylko przeciwko państwu, które przyjęło zobowiązania zgodnie z postanowieniami art. D ZEKS. Podstawę skargi zbiorowej może stanowić naruszenie przez państwo stronę obowiązków przewidzianych w postanowieniach Karty i dobrowolnie przez to państwo przyjętych $^{35}$. Warto $\mathrm{w}$ tym miejscu wyjaśnić, że państwo, które w drodze ratyfikacji staje się stroną EKS, jest zobowiązane do związania się co najmniej pięcioma z siedmiu artykułów określających tzw. hard core provisions. Ponadto państwo takie jest zobowiąane do wybrania spośród pozostałych artykułów części II Karty, stanowiących tzw. non-hard core provisions, tylu przepisów, aby łączna ich ilość nie była mniejsza niż dziesięć spośród obu grup. Nadto, z uwagi na fakt, że państwa mogą wiązać się nie tylko poszczególnymi artykułami określonymi w części II Karty, ale również szczegółowymi ustępami w ramach tych artykułów - łączna ilość numerowanych ustępów, którymi dane państwo jest związane, nie może być mniejsza niż 45 . Natomiast w przypadku ZEKS państwo, które w drodze ratyfikacji staje się jej strona, jest zobowiązane do związania się co najmniej sześcioma z dziewięciu artykułów, które

${ }^{32}$ Pojęcie ,reprezentatywne organizacje” wyjaśnił EKPS w procesie rozpatrywania skargi nr 6/1999 - Syndicat national des professions du tourisme c. France; zob. też Réclamation No. 9/2000 - Confédération Française de l'Encadrement CFE-CGC c. France.

${ }^{33} \mathrm{~S}$. Trechsel, La mise en œuvre de la procédure de réclamations collectives, w: La Charte sociale du XXI ème siècle. Colloque organisé par la Secrétariat Général du Conseil de l'Europe, Strasbourg 14-16 mai 1997, Conseil de l'Europe 1997, s. 116-119. Do tej pory tylko Finlandia upoważniła takie organizacje do składania skarg zbiorowych.

${ }^{34}$ Np. Réclamation No. 16/2003 - Confédération Française de l'Encadrement (CFE CGC) c. France.

${ }^{35} \mathrm{H}$. Cullen, The collective complaints system of the European Social Charter: interpretative methods of the European Committee of Social Rights, „Human Rights Law Review” 9(1), 2009, s. 61 i n. 
określają tzw. hard core provisions. Ponadto państwo takie jest zobowiązane do wybrania spośród pozostałych artykułów części II Karty, stanowiących tzw. non-hard core provisions tylu przepisów, aby łączna ich ilość nie była mniejsza niż szesnaście spośród obu grup. Artykuł A przewiduje jeszcze jedną możliwość związania się przez państwo Karta. Ponieważ państwa mogą wiązać się nie tylko poszczególnymi artykułami określonymi w części II, ale również szczegółowymi ustępami w ramach tych artykułów, łączna ilość numerowanych ustępów, którymi dane państwo jest związane, nie może być mniejsza niż 63 . Poza postanowieniami art. A części III ZEKS warto zwrócić uwagę na postanowienia art. B. Określa on związki pomiędzy ZEKS i EKS oraz Protokołem dodatkowym z 1988 r. Stanowi on, że żadne państwo strona EKS lub Protokołu dodatkowego z 1988 r. nie może ratyfikować, przyjąć lub zatwierdzić ZEKS, nie uznając się za związane przynajmniej postanowieniami odpowiadającymi postanowieniom EKS i Protokołu dodatkowego, którymi było związane.

Z tego właśnie powodu państwa strony EKS i ZEKS są w istocie rzeczy związane ich postanowieniami $\mathrm{w}$ różnym, a nie $\mathrm{w}$ równym zakresie. $\mathrm{W}$ praktyce więc rzadko zdarza się, aby dwa państwa strony systemu normatywnego EKS były związane dokładnie takimi samymi postanowieniami obu Kart i Protokołów. W związku z tym podmioty uprawnione do składania skarg muszą bardzo ostrożnie formułować zarzuty. Warunki ratione materiae są więc bardzo ważne w procesie formułowania skarg zbiorowych i ich kierowania do Komitetu.

W praktyce EKPS były skargi, które Komitet uznał za niedopuszczalne właśnie z powodu zarzutu naruszenia zobowiązań wynikajaccych z tych artykułów Karty, których państwo nie przyjęło. Jako przykład może służyć Réclamation No. 3/1999 par la Fédération européenne du personnel des services publics (EUROFEDOP) contre la Grèce. Skarga nie została przyjęta, gdyż Grecja, która jest stroną Protokołu, nie wyraziła zgody na związanie się spornymi artykułami EKS (art. 5 i 6), których naruszenie EUROFEDOP zarzucała Grecji.

$\mathrm{W}$ praktyce podstawę do wniesienia przez uprawniony podmiot $\mathrm{w}$ ramach jego legitymacji czynnej skargi zbiorowej do Komitetu stanowić mogą zwłaszcza następujące zarzuty: niewypełnienie przez państwo obowiązku przestrzegania przyjętych postanowień EKS oraz niewypełnienie przez państwo standardów EKPS w zakresie prawa pracy, zabezpieczenia społecznego i polityki socjalnej. Zarzuty takie powinny mieć charakter ogólny, a nie indywidualny. Komitet Ministrów Rady Europy wykluczył możliwość wnoszenia skarg w indywidualnych przypadkach naruszenia przez państwo określonych praw socjalnych ${ }^{36}$. Uzasadnia to sformułowaną wyżej tezę na temat skarg zbiorowych jako swego rodzaju actio popularis.

\section{Dopuszczalność skargi - warunki ratione temporis}

W systemie EKS nie ma postanowień na temat rygorów czasowych odnośnie do wniesienia skargi zbiorowej. Jak to już zostało podkreślone wyżej, nie stanowi przeszkody do wniesienia skargi fakt, że sprawa toczy się lub zakoń-

${ }^{36}$ Explanatory report to the 1995 Protocol, w: European Social Charter. Collective texts, Council of Europe, Strasbourg 2003, s. 155. 
czyła się przed odpowiednim organem państwa strony. Nie obowiązuje więc zasada ne bis in idem ani res iudicata. Nie ma też obowiązu wyczerpania drogi postępowania krajowego przed wniesieniem skargi do EKPS. Przesłanki ratione temporis odnośnie do skutecznego wniesienia skargi do Komitetu można więc oceniać z punktu widzenia ogólnych zasad prawa traktatów, które są określone przede wszystkim w Konwencji wiedeńskiej z 23 maja 1969 r., a pośród nich szczególną rolę odgrywa zasada pacta sunt servanda ${ }^{37}$. Przesłanką ratione temporis dopuszczalności skargi zbiorowej jest więc wniesienie jej w czasie, kiedy państwo posiada status strony Protokołu dodatkowego z 1995 r. Państwo, wyrażając zgodę ostateczną na związanie się Protokołem, nie może przy tym zastrzec okresu, do jakiego mogą się odnosić skargi. Zgodnie z jego postanowieniami skargi moga dotyczyć każdego naruszenia praw gospodarczych i socjalnych, jakie miały w odniesieniu do państwa miejsce od chwili jego przyjęcia. W związku z tym K. Łasak, powołując się na dotychczasową praktykę Komitetu, konstatuje, że na gruncie tej praktyki można przyjąć koncepcję naruszenia ciagłego. Polega ona na możliwości zaskarżenia niewłaściwej implementacji przez państwo praw objętych systemem Karty, która się rozpoczęła, zanim państwo stało się stroną Protokołu, i trwa nadal ${ }^{38}$.

\section{Dopuszczalność skargi - warunki ratione loci}

Zasadą prawa traktatów jest, że umowa obowiąuje i jest stosowana na całym terytorium państwa strony ${ }^{39}$. Potwierdzają tę zasadę EKS i ZEKS, formułują jednak możliwości pewnych wyłączeń. Z treści art. 34 Karty i art. L ZEKS wynika, że postanowienia tych umów będą stosowane na terytorium metropolitalnym każdego państwa strony. Każde takie państwo może jednak w momencie wiązania się tymi umowami określić w drodze oświadczenia terytorium, które będzie uważane za metropolitalne. Każde państwo może również w podobny sposób złożyć oświadczenie o obowiązywaniu tych umów w całości lub w części na terytorium lub terytoriach niemetropolitalnych.

W świetle postanowień Załącznika do ZEKS ochrona przewidziana w systemie EKS rozciąga się również na obcokrajowców, jeżeli są oni obywatelami innych państw stron, legalnie mieszkajacymi lub pracującymi na terytorium innego państwa strony, a nadto może zostać rozciagnięta na inne osoby. W określonym zakresie Karta zapewnia również ochronę praw socjalnych uchodźców i bezpaństwowców, legalnie zamieszkujących na terytorium państw stron ${ }^{40}$.

Takie sformułowania Karty rodzą w praktyce wiele różnych problemów dotyczących interpretacji postanowień dotyczacych terytorialnego i podmiotowego zakresu ochrony, czego wyrazem są skargi do EKPS. Problemy te związane są często z ochroną socjalną nielegalnych imigrantów, np. Romów

37 UNTS 1155:354 (tekst polski: Dz. U. 1990, Nr 74, poz. 439).

${ }^{38}$ K. Łasak, op. cit., s. 246.

39 Art. 29 Konwencji wiedeńskiej.

${ }^{40}$ Załącznik odwołuje się w tej sprawie do: Konwencji dotyczącej statusu uchodźców sporządzonej w Genewie z 28 lipca 1951 r. wraz z Protokołem dodatkowym z 31 stycznia 1967 r., UNTS 189:137 oraz UNTS 606:267 (Dz. U. 1991, Nr 119, poz. 515, 517) oraz do Konwencji dotyczącej statusu bezpaństwowców z 1954 r., UNTS 360:117. 
w niektórych państwach członkowskich Rady Europy. Dla przykładu, w orzeczeniu w sprawie skargi przeciwko Bułgarii Komitet orzekł, że zmiana przepisów o pomocy społecznej w tym państwie była sprzeczna z art. 13 jako norma prawna gwarantująca prawo podmiotowe do świadczeń z pomocy społecznej, jak również naruszała prawo do równego traktowania i zakaz dyskrymina$\mathrm{cji}^{41}$. W orzeczeniu w sprawie skargi przeciwko Grecji Komitet stwierdził, że w zakresie zagwarantowania Romom odpowiednich warunków mieszkaniowych władze tego państwa nie przestrzegały europejskich standardów w dziedzinie praw rodzin do socjalnej, prawnej i ekonomicznej ochrony, jak również $\mathrm{w}$ dziedzinie ochrony przed dyskryminacja ${ }^{42}$. W dwóch innych orzeczeniach: w sprawie skargi przeciwko Francji i Włochom Komitet orzekł, że władze obu państw nie podejmowały odpowiednich działań w celu zagwarantowania rodzinom Romów, czasowo przebywającym na ich terytorium, właściwej pomocy i ochrony przed ubóstwem i marginalizacją społeczna ${ }^{43}$. W tym samym orzeczeniu w sprawie skargi przeciwko Francji Komitet poszedł jeszcze dalej i orzekł, że nie popierając dostępu Romów do miejsc zamieszkania dostosowanych do stylu ich życia, władze francuskie nie dopełniły konwencyjnych obowiązków, a zwłaszcza złamały zakaz dyskryminacji. Podobne działanie władz włoskich w sprawie skargi 58/2009 Komitet uznał za faktyczna segregację Romów, powołując się na podobne postanowienia Karty ${ }^{44}$.

\section{KONKLUZJE}

Nie jest łatwo jednoznacznie zaklasyfikować EKPS na tle innych organów traktatowych funkcjonujacych w procesie implementacji międzynarodowego prawa praw człowieka. Komitet jako organ traktatowy w systemie EKS nie jest, co do zasady, organem sądowym, takim jak np. ETPC w systemie EKPC. Nie rozstrzyga zatem indywidualnych skarg o naruszenie przez państwa strony EKS postanowień umów składających się na system Karty. W jego skład nie wchodzą sędziowie, ale niezależni eksperci. W praktyce realizacji swoich zadań kontrolnych EKPS podejmuje działania, które sa charakterystyczne dla pozasądowego organu traktatowego, ale z drugiej strony jego kompetencje idą dalej, jako że realizuje on działania, które świadczą o jego quasi-sądowym charakterze ${ }^{45}$. Dotyczy to zwłaszcza procedury rozpatrywania skarg zbiorowych na podstawie Protokołu dodatkowego z 1995 r. ${ }^{46} \mathrm{Na}$ poparcie tej

\footnotetext{
${ }^{41}$ Réclamation No. 48/2008 - Centre européen des Droits des Roms c. Bulgarie.

${ }^{42}$ Réclamation No. 49/2008 - International Centre for the Legal Protection of Human Rights (INTERIGHTS) c. Grèce.

${ }^{43}$ Réclamation No. 51/2008 - Centre européen des Droits des Roms (CEDR) c. France i Réclamation No. 58/2009, Centre on Housing Rights and Evictions (COHRE) c. Italie.

${ }^{44}$ A. Świątkowski, Prawa społeczne Romów $w$ świetle europejskiej procedury skarg zbiorowych, „Polityka Społeczna” 38, 2011, nr 2(443).

${ }^{45}$ R. R. Churchill, U. Khaliq, op. cit., s. 445 i n.

${ }^{46}$ Szerzej np. R. Brillant, The supervisory machinery of the European Social Charter: recent developments and their impact, w: G. de Burca, B.de Witte (red.), Social Rights in Europe, Oxford
} 
tezy i na podstawie zaprezentowanych wyżej rozważań należałoby przywołać kilka najważniejszych argumentów. Są one następujące:

1) EKPS rozpatruje skargi zbiorowe, kierowane do niego przez uprawnione podmioty. Skargi takie, chociaż nie są składane przez państwo lub państwa, zbliżają się swoim charakterem do actio popularis, co jest cechą skarg międzypaństwowych, a nie indywidualnych;

2) EKPS nie wydaje jednak orzeczeń, które w przypadku organów sądowych maja charakter wyroków. Raporty Komitetu w sprawie skarg zbiorowych, które zawieraja konkluzje, nie są wiążące. Rozpatruje je Komitet Ministrów Rady Europy, który uchwala odpowiednie rezolucje lub rekomendacje;

3) EKPS posiada i realizuje kompetencje do badania legitymacji podmiotów skarżących do wnoszenia skargi i decyduje o dopuszczalności takiej skargi (przesłanka ratione personae);

4) istotnym elementem postępowania quasi-sądowego w sprawach skarg zbiorowych jest wstępne badanie przez EKPS skargi oraz orzekanie o jej dopuszczalności. Bada on również przesłanki ratione materiae, ratione temporis i ratione loci;

5) postępowanie przed EKPS w sprawie skarg zbiorowych ma charakter kontradyktoryjny. Każda ze stron jest zobowiązana do przedstawienia na piśsmie twierdzeń i dowodów uzasadniających zarzuty zawarte w skardze, jak i w odpowiedzi na skargę;

6) jeżeli z locus standi korzystają organizacje wymienione w art. 1 pkt b oraz c Protokołu dodatkowego, Komitet zawiadamia, za pośrednictwem Sekretarza Generalnego Rady Europy, międzynarodowe organizacje pracodawców i związków zawodowych wymienione w art. 27 EKS o postępowaniu, w celu umożliwienia im przedstawiania swoich opinii w sprawie i wystapienia w niej w charakterze amicii curiae;

7) nie stanowi formalnej przeszkody do przekazania i rozpoznania skargi zarzut sprawy zawisłej przed innym organem, jak również zarzut sprawy osądzonej (res iudicata);

8) w postępowaniu wszczętym skarga zbiorową nie ma zastosowania zakaz powtórnego wyrokowania w jednej sprawie (ne bis in idem);

9) nie ma również formalnych przeszkód do wniesienia i rozpoznania skargi, która została już rozpoznana przez inną organizację lub sam Komitet, np. w ramach procedury sprawozdań;

10) nie ma też obowiązku wyczerpania drogi postępowania krajowego przed wniesieniem skargi do Komitetu.

Pomimo generalnie pozytywnych ocen funkcjonowania systemu kontrolnego EKS, a w jego ramach instytucji skarg zbiorowych, wydaje się, że ocena ta nie może być wyłącznie pozytywna. Tylko 15 państw ratyfikowało dotąd Protokół dodatkowy z 1995 r. Nie jest to dużo w skali 47 państw członkowskich Rady Europy, a nawet w skali 27 państw stron EKS, czy 34 państw stron ZEKS. W związku z tym należy sformułować postulat istotnego rozsze-

Univ. Press, Oxford 2005, s. 32 i n.; zob. też interesujące rozważania członka EKPS - K. Lukas, The collective complaint procedure of the European Social Charter: some lessons for the EU?, „Legal Issues of Economic Integration" 41(3), 2014, s. 275 i n. 
rzenia zakresu podmiotowego obowiązywania Protokołu, jak również wzmocnienia pozycji EKPS i Komitetu Rady Ministrów Rady Europy w procesie kontrolnym. Chodzi zwłaszcza o potrzebę zmobilizowania państw stron Karty do bardziej powszechnej ratyfikacji Protokołu. Zapewne nie będzie to łatwe, ponieważ w ciagu ostatnich dziesięciu lat tylko dwa państwa ratyfikowały Protokół ${ }^{47}$. Niektóre państwa wyraźnie deklarują brak zainteresowania taka ratyfikacja, podkreślając stosunkowo mała, w ich opinii, skuteczność skarg zbiorowych w praktyce. W swojej argumentacji zwracają one zwykle uwage na wystarczającą skuteczność sprawozdań państw jako klasycznego instrumentu kontrolnego w dziedzinie implementacji regulacji normatywnych międzynarodowego prawa praw człowieka ${ }^{48}$.

mgr Aleksander Gadkowski

Uniwersytet im. Adama Mickiewicza w Poznaniu

alga@amu.edu.pl

\author{
CHARACTERISTICS OF QUASI-JUDICIAL COMPETENCES \\ OF THE EUROPEAN COMMITTEE OF SOCIAL RIGHTS \\ IN THE COURSE OF REVIEWING COLLECTIVE COMPLAINTS
}

Sum mary

The article presents the competences of the European Committee of Social Rights in monitoring States' compliance with the European Social Charter. The Council of Europe's treaty acquis in the field of the protection of human rights and fundamental freedoms is rich and extensive, and the system of monitoring States' compliance which it has established may be regarded as a reference model for other international organisations. The system of supervising compliance within the European Social Charter is analysed with an emphasis on its main institution - the European Committee of Social Rights - considered to be a particular treaty body. While ruling on the conformity of the situation in States with the European Social Charter, the Committee employs both the classical instruments of control, that is national reports submitted by States, as well as specific instruments of control, that is collective complaints. In reviewing collective complaints, the European Committee of Social Rights undertakes actions which justify the stance of the Committee being equipped with quasi-judicial competences. Arguments to support this thesis have been offered.

\footnotetext{
47 Holandia (2006) i Republika Czeska (2012).

48 Takie stanowisko zaprezentował też polski minister pracy i polityki socjalnej w Sejmie w 2006 r. (interpelacja nr 3739). Polska nie ratyfikowała dotąd ani Protokołu, ani ZEKS.
} 